\section{La Antropología Física entre la universidad y el Estado. Análisis de un grupo académico universitario y sus relaciones con las políticas públicas del Instituto Étnico Nacional (1946-1955)}

Germán Soprano
Germán Soprano es Profesor de las Universidades Nacionales de La Plata y de Quilmes, e Investigador del CONICET, con sede en esta última universidad.

Roque Sáenz Peña 352, oficina 203. Bernal (1876) Prov. de Buenos Aires, Argentina. Teléfono: 011-43657100, interno 246.

e-mail: gsoprano@speedy.com.ar

\section{Resumen}

Este trabajo analiza dos cuestiones relacionadas. Por un lado, la configuración de un grupo profesores e investigadores en el Instituto del Museo y Facultad de Ciencias Naturales de la Universidad Nacional de La Plata, organizado en torno del liderazgo académico Milcíades Alejo Vignati y especializados en antropología física. Por otro lado, estudia la participación de un miembro de ese grupo -Luis María Bergna- en el Instituto Étnico Nacional durante los gobiernos peronistas de 1946-1955. De este modo, el artículo considera la circulación de individuos, saberes y experiencias entre el Estado y la universidad en un período de la historia argentina caracterizado por la existencia de una radical oposición entre el gobierno nacional y los proyectos e intereses de los académicos.
Los temas abordados en este artículo forman parte de un proyecto de investigación del CONICET con sede en la Universidad Nacional de Quilmes y del PICT Redes 1728 de la ANPCyT dirigido por Rosana Guber. El autor agradece los comentarios críticos efectuados a versiones de este texto por Carolina Biernat, Nicolás Quiroga, Laura Graciela Rodríguez, Ernesto Bohoslavsky, Mirta Bonnín, Patricia Arenas, Karina Ramaciotti, María Liliana Da Orden; los colegas del PICT; y los evaluadores anónimos de Estudios Sociales, asumiendo, como es de rigor, la responsabilidad por los errores que pueda contener el trabajo.

\section{Summary}

This work analyzes two related questions. On one hand, the configuration of a group of professors and investigators in the Instituto del Museo y Facultad de Ciencias Naturales de la Universidad Nacional de La Plata, organized around the academic leadership of Milcíades Alejo Vignati and specialized in physical anthropology. On the other hand, the paper studies the participation of a member of that group -Luis María Bergna- in the Instituto Étnico Nacional during Peron's governments of 1946-1955. In this way, the article considers the circulation of individuals, knowledge and experiences between the State and the university in a period of the Argentinean history characterized by the existence of a radical opposition between the national government and the projects and the academics' interests. 